\title{
Fungal Community Assembly in the Amazonian Dark Earth
}

\author{
Adriano Reis Lucheta ${ }^{1}$. Fabiana de Souza Cannavan ${ }^{2}$. \\ Luiz Fernando Wurdig Roesch $^{3} \cdot$ Siu Mui Tsai ${ }^{2} \cdot$ Eiko Eurya Kuramae $^{1}$
}

Received: 15 May 2015 / Accepted: 30 October 2015 / Published online: 19 November 2015

(C) The Author(s) 2015. This article is published with open access at Springerlink.com

\begin{abstract}
Here, we compare the fungal community composition and diversity in Amazonian Dark Earth (ADE) and the respective non-anthropogenic origin adjacent (ADJ) soils from four different sites in Brazilian Central Amazon using pyrosequencing of $18 \mathrm{~S}$ ribosomal RNA (rRNA) gene. Fungal community composition in ADE soils were more similar to each other than their ADJ soils, except for only one site. Phosphorus and aluminum saturation were the main soil chemical factors contributing to ADE and ADJ fungal community dissimilarities. Differences in fungal richness were not observed between ADE and ADJ soil pairs regarding to the most sites. In general, the most dominant subphyla present in the soils were Pezizomycotina, Agaricomycotina, and Mortierellomycotina. The most abundant operational taxonomic units (OTUs) in ADE showed similarities with the entomopathogenic fungus Cordyceps confragosa and the saprobes Fomitopsis pinicola, Acremonium vitellinum, and Mortierellaceae sp., whereas OTUs similar to Aspergillus
\end{abstract}

Adriano Reis Lucheta and Fabiana de Souza Cannavan share first authorship.

Electronic supplementary material The online version of this article (doi:10.1007/s00248-015-0703-7) contains supplementary material, which is available to authorized users.

Eiko Eurya Kuramae

e.kuramae@nioo.knaw.nl

1 Department of Microbial Ecology, Netherlands Institute of Ecology (NIOO/KNAW), Droevendaalsesteeg 10, Wageningen 6708 PB, The Netherlands

2 Centro de Energia Nuclear na Agricultura (CENA), Universidade de São Paulo (USP), Piracicaba, Brazil

3 Centro Interdisciplinar de Pesquisas em Biotecnologia (CIP-Biotec), Universidade Federal do Pampa, São Gabriel, Brazil niger, Lithothelium septemseptatum, Heliocephala gracillis, and Pestalosphaeria sp. were more abundant in ADJ soils. Differences in fungal community composition were associated to soil chemical factors in $\mathrm{ADE}(\mathrm{P}, \mathrm{Ca}, \mathrm{Zn}, \mathrm{Mg}$, organic matter, sum of bases, and base saturation) and ADJ (Al, potential acidity, Al saturation, $\mathrm{B}$, and $\mathrm{Fe}$ ) soils. These results contribute to a deeper view of the fungi communities in ADE and open new perspectives for entomopathogenic fungi studies.

Keywords 18S rRNA · Anthrosols $\cdot$ Biochar $\cdot$ Microbial ecology $\cdot$ Pre-Columbian soil $\cdot$ Pyrosequencing

\section{Introduction}

Amazonian Dark Earth (ADE), also referred to as "Terra Preta", was described by Sombroek [1] as a "well-drained soil characterized by the presence of a thick black or dark gray topsoil which contains pieces of artifacts". The anthropogenic, pre-Columbian soils occur in 20-ha average spots in the Amazonian region [2]. ADE is recognized by the elevated amounts of stable carbon (70 times more black carbon) and fertility due to the high concentration of $\mathrm{P}, \mathrm{Ca}, \mathrm{Mg}$, and $\mathrm{Zn}$, nutrient holding capacity, and higher $\mathrm{pH}$ when compared to adjacent non-anthropogenic origin soils [3, 4]. Despite evidences of human occupation in the Amazon region dating 10,000 years BP (before present), Neves and co-workers [5] suggested that ADE formation occurred 2500 to 2000 years ago as a result of population increasing during that period. It is still unclear if the ADE was intentionally created or if it was a result of disposals by native settlements. However, the consensus is that the main sources of ADE nutrients originated from human and animal excrements, plant and animal 
residues, mammalian and fish bones, housing material and pottery debris, ash, and charred organic materials $[2,5,6]$.

Another remarkable characteristic of ADE is the elevated microbial diversity and associated bacterial species richness [7]. Using culture dependent and independent approaches, studies reveal bacterial and archaeal communities in ADE that are distinct from the adjacent soil or from isolated black carbon [8-10].

Significant advances in soil microbial ecology studies were obtained in the last few years after the adoption of highthroughput $16 \mathrm{~S}$ ribosomal RNA (rRNA) gene sequencing technologies [11]. This approach was used to investigate the bacterial community associated with biochar samples of ADE [12] and the effect of ADE and plant species on the selection of rhizosphere bacterial communities [4]. However, the fungal communities associated with ADE have not yet been investigated with culture-independent methods despite the ecological importance of fungi in terrestrial ecosystems. The degradation of organic matter, mainly by saprophytic fungi, controls the balance between soil and atmospheric carbon and releases nutrients for plant uptake [13-15]. The fungal community in ADE has been poorly characterized and evaluated only by low-resolution culture-dependent methods [16]. The application of high-throughput sequencing technologies will expand the knowledge of ADE fungal diversity. Comparison to low fertility adjacent soils will help to elucidate the carbon transformations by fungi in these soils and to evaluate potential land use and climate change effects for future studies. Therefore, the aim of this study was to estimate the fungal richness and diversity associated to ADE and to adjacent soils from four sites in the Central Amazon through pyrosequencing of $18 \mathrm{~S}$ rRNA gene fragments.

\section{Materials and Methods}

\section{Site Description and Soil Sampling}

The study area was comprised of four locations in the Brazilian Central Amazonia region near Manaus, the capital of Amazonas state (AM). ADE and the respective adjacent (ADJ) non-anthropogenic origin soils were collected at (1) Açutuba (ACU, 03 05' 53.92" S, 60 21' 19.90" W), located at the margin of Negro River close to the municipality of Iranduba (AM), under cultivation of eggplant (ADE) and pasture (ADJ) at the time of sampling; (2) Balbina (BAL, $01^{\circ} 30^{\prime}$ $24.4^{\prime \prime}$ S, $60^{\circ} 05^{\prime} 34^{\prime \prime} \mathrm{W}$ ), located at the Presidente Figueiredo municipality and characterized by the presence of an undisturbed secondary forest. This site has not been deforested or used for agriculture purposes for at least 20 years [17]; (3) Hatahara (HAT, $03^{\circ} 16^{\prime} 28.45^{\prime \prime} \mathrm{S}, 60^{\circ} 12^{\prime} 17.14^{\prime \prime} \mathrm{W}$ ) located in a bluff on the margin of Solimões river cultivated with banana plants (ADE) and pasture (ADJ). This is one of the most studied archaeological ADE sites in Central Amazon [18]; (4) Barro Branco (BBO, 03 18' 24.76" S, 60 32' $\left.5.10^{\prime \prime} \mathrm{W}\right)$, located upstream Hatahara in the margin of Solimões River close to Manacapuru (AM) under a citrus orchard (ADE) and cassava plantation (ADJ).

The soil sampling scheme in each site was set by a georeferenced central point $(\mathrm{A})$ and four extra points $1.5 \mathrm{~m}$ distant in the cardinal direction (B, C, D, E). Each soil sample was composed by five subsamples (A1, A2, A3, A4, A5, B1, B2, $\mathrm{B} 3, \mathrm{~B} 4, \mathrm{~B} 5$, etc.) collected $0.3 \mathrm{~m}$ around the main point at 0 $10 \mathrm{~cm}$ depth using sterile plastic cylinders $(5-\mathrm{cm}$ diameter). Sampling scheme illustration can be viewed in Online Resource 1. To minimize the current land use effect, grass layer and litter were removed, and then, the soil samples were collected in the space between rows when cultivated. Soil samples were kept on dry ice before storage at $-20^{\circ} \mathrm{C}$. Soil physicochemical attributes were determined following Raij et al. [19] in the Soil Fertility Laboratory of the Department of Soil Sciences, University of São Paulo (ESALQ-USP). Fieldwork was conducted under legal authorization (SISBIO 4845833).

\section{DNA Extraction, Amplification, and Sequencing of $18 \mathrm{~S}$ rRNA Gene Fragment}

Total DNA was extracted from $250 \mathrm{mg}$ of bulk soil in triplicate from only three of the five soil samples (A, B, D) using the Power Soil DNA isolation kit (MO BIO Laboratories Inc., Carlsbad, CA, USA) following the manufacturer's instructions. Extracted DNA was quantified using a NanoDrop ND-1000 spectrophotometer (Thermo Scientific, Wilmington, DE, USA). The $18 \mathrm{~S}$ rRNA gene fragments were amplified by polymerase chain reaction (PCR) using $0.5 \mu \mathrm{M}$ of the fungalspecific reverse primer FR1 [20] and the modified version (to include Glomeromycota arbuscular mycorrhizal fungi) of forward primer FF390w (5'-CGWTAACGAACGAGACCT-3') [21]. Four PCR reactions $(25 \mu \mathrm{L})$ per extracted sample DNA were carried out using $2.5 \times$ reaction buffer containing $18 \mathrm{mM}$ of $\mathrm{MgCl}_{2}, 0.2 \mathrm{mM}$ of each dNTP, $0.5 \mu \mathrm{M}$ of each primer, $25 \mathrm{ng}$ of template DNA, $1 \mathrm{U}$ Taq polymerase FastStart High Fidelity (Roche Applied Sciences, Indianapolis, IN, USA), and sterile water to $25 \mu \mathrm{L}$ final volume. The thermocycling conditions were initial denaturing at $94{ }^{\circ} \mathrm{C}$ for $4 \mathrm{~min}, 29$ cycles of $94{ }^{\circ} \mathrm{C}$ for $30 \mathrm{~s}, 55^{\circ} \mathrm{C}$ for $1 \mathrm{~min}$ (annealing temperature was lowered $2{ }^{\circ} \mathrm{C}$ every 2 cycles until $47{ }^{\circ} \mathrm{C}$ ), and extension at $68^{\circ} \mathrm{C}$ for $2 \mathrm{~min}$. The technical PCR replicate (12 PCR reactions/soil replicate) amplicons were pooled and cleaned with the Qiagen PCR purification kit (Qiagen, Valencia, CA, USA) to avoid amplification bias. A total of 24 soil samples (4 sites $\times 2$ soil types $\times 3$ replicates) were amplified using barcoded primers (MID tags) for multiplex pyrosequencing in a Roche 454 GS FLX automated sequencer (454 Life Sciences, Brandford, CT, 
USA) using titanium chemistry. The complete list of barcoded primers is listed in Online Resource 2.

\section{Bioinformatics and Statistical Analysis}

The 18S rRNA gene sequences were analyzed using QIIME 1.8.0 [22] following the suggested $18 \mathrm{~S}$ data analysis tutorial (http://qiime.org/1.8.0/tutorials/processing_18S_data.html). Multiplex sequence libraries were split into the original samples based on the specific barcodes. The 454 reads were denoised using Denoiser [23] and chimeric sequences checked with UCHIME [24]. Operational taxonomic units (OTUs) were clustered considering evolutionary distance of 0.03 (97\% similarity cutoff) by using UCLUST algorithm [25] and taxonomically affiliated through BLAST search using QIIME BLAST Taxon Assigner default parameters (application blastn/megablast, max $E$ value 0.001 , min percentage identity 90.0) against SILVA Eukaryotic database (97 SILVA 111 rep set euk) [26, 27]. OTUs not assigned to Fungi kingdom, singletons (OTUs containing a unique sequence in the whole analysis) as well as classified as "no hit" by BLAST search were removed from the dataset. Inconsistences of SILVA taxonomic classification were manually corrected before relative abundance calculation based on the OTU BLAST search best hit access number and NCBI taxonomy rank (http://www.ncbi.nlm.nih.gov/taxonomy). The OTU table was rarefied to the lowest number of sequences in any sample (1728) before calculation of alpha diversity indices. Species richness (Chaol and Abundance Coverage-based Estimator (ACE)), diversity (Shannon, Simpson's reciprocal) estimators, Good's coverage, and rarefaction curves were calculated in QIIME. Chao entropy index [28] was calculated on the CHAOEntropy-Online calculator (https://yuanhan.shinyapps.io/ChaoEntropy/). A bipartite OTU network was generated in QIIME and viewed and edited in Cytoscape 3.2.1 [29]. The fungal OTUs present in all soil samples (total core) (core_table_100.biom file), as well as the common OTUs belonging to ADE or ADJ soils (group core) were also determined in QIIME (compute_core_ microbiome.py). OTUs showing average abundance higher than $1 \%$ of the total number of sequences by group (ADE or ADJ) were considered abundant. Differential OTU frequencies between $\mathrm{ADE}$ and $\mathrm{ADJ}$ soil groups was determined by non-parametric $t$ test followed by Monte Carlo test (100 replicates) after removing the OTUs that were not represented in at least $25 \%$ of the samples using QIIME (group_significance.py). Univariate analyses ( $t$ test, ANOVA, Tukey's test) were performed using IBM SPSS Statistics V.22 (IBM Corp., Armonk, NY, USA) software, whereas multivariate analyses (canonical correspondence analysis and similarity percentage analysis) were performed using paleontological statistics (PAST) software package V.3.05 [30]. Count data (sequence abundances) and environmental variable values were transformed (function $\log (x+1)$ ) before multivariate analysis. The raw 454 pyrosequencing data of the $18 \mathrm{~S}$ rRNA are available at the European Nucleotide Archive (ENA) (https://www.ebi.ac.uk/ena/) under the study accession number PRJEB10851.

\section{Results}

\section{Soil Physicochemical Properties}

All the evaluated soil physicochemical and fertility attributes were statistically different $(p \leq 0.05)$ when ADE and ADJ soils were compared in groups, with the exception of the K, S, and $\mathrm{Fe}$ attributes. On average, ADE soils were higher in $\mathrm{pH}$, organic matter $(\mathrm{OM})$, macronutrients $(\mathrm{P}, \mathrm{Ca}, \mathrm{Mg})$, and some micronutrients $(\mathrm{Mn}, \mathrm{Cu}$ and $\mathrm{Zn}$ ), while ADJ soils had higher levels of $\mathrm{Al}$ and $\mathrm{H}+\mathrm{Al}$ (Table 1). Within the ADE soil group, the Hatahara sample showed the highest amounts of $\mathrm{P}, \mathrm{Cu}, \mathrm{Fe}$, $\mathrm{Zn}$, and $\mathrm{Mn}$, whereas in the ADJ soil group, the Açutuba soil sample showed the highest amount of $\mathrm{K}$ and lowest $\mathrm{Al}$ concentration and Al saturation, comparable with ADE samples (Table 1).

\section{Diversity of Fungal Community}

\section{$18 S$ rRNA Sequencing}

Pyrosequencing of $18 \mathrm{~S}$ rRNA gene from the 24 soil samples generated 132,764 high-quality sequences after denoising and chimera checking, with an average size of 351 nucleotides. A total of 105,019 sequences were used for further analysis after taxonomic classification as fungal. The numbers of sequences per library ranged from 1728 to 6712 . A detailed description of sequencing depth and number of OTUs along the bioinformatics analyses can be viewed at Online Resource 3. The number of picked OTUs ranged between 127 and 172 after the removal of singletons and library normalization with the lowest number of sequences (1728) (Table 2). Despite the decrease in the number of sequences after quality filtering and library normalization (Online Resource 3), the sample coverage was approximately $97 \%$ as indicated by Good's estimator (Table 2). In addition, rarefaction curves also pointed for adequate sequencing efforts for fungal population coverage in the samples (Online Resource 4).

No significant differences in the estimated species richness was observed by ACE and Chao1 estimators when comparing the ADE and ADJ soil samples in the same sites, with exception of a higher number of species in the Hatahara ADE sample in relation to its ADJ soil (ACE estimator). Regarding the fungal species diversity, Shannon and Chao entropy estimators also pointed to no differences between the ADE and ADJ soils. Simpson's reciprocal indicated lower species diversity 


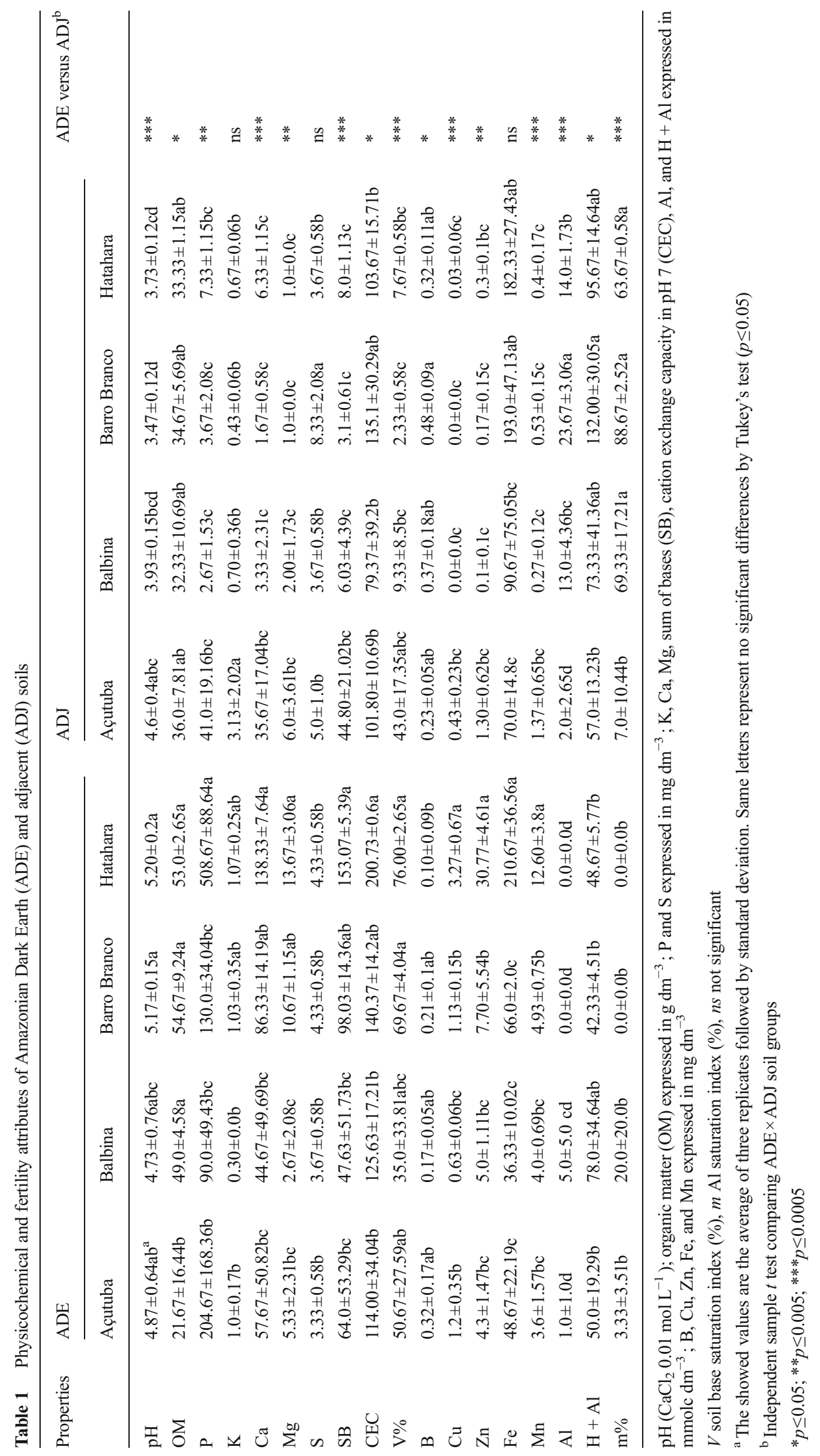


Table 2 Estimated richness and diversity indices for the fungal communities in the Amazonian Dark Earth (ADE) and adjacent (ADJ) soils from Açutuba (ACU), Balbina (BAL), Barro Branco (BBO), and Hatahara (HAT) sites

\begin{tabular}{|c|c|c|c|c|c|c|c|}
\hline \multirow[b]{2}{*}{$\begin{array}{l}\text { Soil } \\
\text { type/site }\end{array}$} & \multirow[b]{2}{*}{$N$ OTUs $^{\mathrm{a}}$} & \multicolumn{2}{|c|}{ Species richness estimators } & \multicolumn{3}{|l|}{ Diversity estimators } & \multirow[b]{2}{*}{ Good's ${ }^{f}$} \\
\hline & & ACE & Chao-1 & $1 / \mathrm{D}^{\mathrm{c}}$ & $H^{\prime \mathrm{d}}$ & Chao entropy ${ }^{\mathrm{e}}$ & \\
\hline \multicolumn{8}{|l|}{$\mathrm{ADE}$} \\
\hline $\mathrm{ACU}$ & $136(183,89)^{\mathrm{b}}$ & $200.14(239.10,161.17)$ & $197.06(245.57,148.54)$ & $10.30(16.66,3.94)$ & $4.58(5.86,3.31)$ & $3.24(4.13,2.35)$ & $0.97(0.97,0.96)$ \\
\hline BAL & $132(145,119)$ & $200.28(251.44,149.12)$ & $193.01(262.55,123.48)$ & $6.66(9.27,4.05)$ & $4.19(4.83,3.56)$ & $2.97(3.42,2.52)$ & $0.97(0.98,0.96)$ \\
\hline $\mathrm{BBO}$ & $139(177,102)$ & $210.90(253.77,168.03)$ & $206.80(285.52,128.08)$ & $7.74(11.95,3.53)$ & $4.46(5.33,3.59)$ & $3.16(3.77,2.54)$ & $0.97(0.98,0.96)$ \\
\hline HAT & $172(182,162)$ & $245.40(254.92,235.87)$ & $248.17(294.53,201.81)$ & $20.21(30.11,10.32)$ & $5.60(5.74,5.46)$ & $3.96(4.06,3.86)$ & $0.96(0.97,0.96)$ \\
\hline \multicolumn{8}{|c|}{ 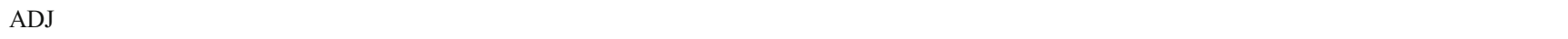 } \\
\hline $\mathrm{ACU}$ & $164(173,155)$ & $236.48(284.49,188.46)$ & $238.93(348.00,129.86)$ & $13.91(15.00,12.82)$ & $5.18(5.29,5.06)$ & $3.66(3.74,3.59)$ & $0.96(0.98,0.95)$ \\
\hline BAL & $166(186,146)$ & $243.53(269.82,217.23)$ & $246.05(326.08,166.02)$ & $15.54(19.64,11.44)$ & $5.22(5.72,4.73)$ & $3.70(4.03,3.37)$ & $0.96(0.97,0.95)$ \\
\hline $\mathrm{BBO}$ & $127(145,109)$ & $191.69(250.32,133.07)$ & $180.82(221.30,140.33)$ & $14.95(16.42,13.48)$ & $4.94(5.10,4.79)$ & $3.49(3.60,3.37)$ & $0.97(0.98,0.96)$ \\
\hline HAT & $138(166,110)$ & $188.47(231.82,145.11)$ & $184.10(202.18,166.02)$ & $15.98(26.94,5.01)$ & $5.12(5.93,4.30)$ & $3.61(4.17,3.04)$ & $0.97(0.98,0.97)$ \\
\hline
\end{tabular}

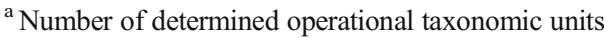

${ }^{b}$ The showed values represent the average of three replicates followed by confidence intervals

${ }^{c}$ Simpson's reciprocal (1/D) index

${ }^{\mathrm{d}}$ Shannon index

${ }^{\mathrm{e}}$ Chao entropy index (Chao et al. 2013)

${ }^{\mathrm{f}}$ Good's estimated sample coverage

in the $\mathrm{ADE}$ from $\mathrm{BAL}$ and $\mathrm{BBO}$ in comparison with the respective ADJ samples (Table 2).

\section{Statistical Multivariate Analysis}

Even though similarities were observed in the species richness and diversity of the ADE and ADJ soil fungal communities, the OTU network and canonical correspondence analysis (CCA) showed two well-defined clusters segregating the fungal communities of $\mathrm{ADE}$ and $\mathrm{ADJ}$ soils from BAL, BBO, and HAT (Fig. 1a, b). The same pattern could not be observed for the fungal communities of ADE and ADJ soils from ACU that were more similar to each other and distant from the other site assemblages (Fig. 1b). CCA also indicated that the ADE fungal assemblages were correlated with higher $\mathrm{pH}$, macronutrients, sum of bases (SB), percentage of soil base saturation (V\%), and $\mathrm{Cu}, \mathrm{Zn}$, and $\mathrm{Mn}$ concentrations, whereas ADJ community was correlated with $\mathrm{Al}, \mathrm{H}+\mathrm{Al}$, aluminum saturation $(\mathrm{m} \%)$, and $\mathrm{B}$ levels (Fig. 1b). $\mathrm{P}$ and $\mathrm{m} \%$ contributed with more than $13 \%$ each in the ADE versus ADJ fungal community dissimilarity as calculated by similarity percentage analysis (SIMPER) (Online Resource 5). Conversely, the $\mathrm{OM}$ and $\mathrm{pH}$ contributed 2.5 and $0.9 \%$ to the dissimilarities, respectively.

\section{Fungal Taxonomy}

The phylum Ascomycota, specifically the subphylum Pezizomycotina, was the most abundant in all the soil samples with exception of BAL ADE that was dominated by
Agaricomycotina fungi (Basidiomycota) (Table 3). Pezizomycotina fungi were statistically significantly ( $p \leq$ 0.05 ) more abundant in ADJ soils, and shifts were detected especially in Balbina and Hatahara sites. Ascomycota Taphiromycotina $(p \leq 0.005)$ and Mitosporic Acomycota $(p \leq$ $0.05)$, Chytridiomycota Insertae sedis $(p \leq 0.005)$, Fungi Insertae sedis Mucoromycotina $(p \leq 0.05)$, and Glomeromycota phylum (arbuscular mycorrhizal fungi) were also more abundant in ADJ soils at statistical significant level.

The ADE soils showed significant higher abundance of Basidiomycota Agaricomycotina $(p \leq 0.05)$ and Pucciniomycotina $(p \leq 0.05)$, Fungi Insertae sedis Zoopagomycotina $(p \leq 0.05)$, and Mortierellomycotina ( $p \leq$ 0.05 ). Shifts in Mortierellomycotina abundance were observed mainly in ACU and HAT sites.

A significant number of sequences, especially in $\operatorname{ADE}(p \leq$ 0.05 ), were taxonomically classified only at Fungi domain and environmental sample category based on BLAST access taxonomy rank. We cannot affirm whether these results could represent new fungal species or are resultant of SILVA and NCBI database annotation imprecision.

\section{Fungal Core Community}

The fungal core community present in all soil samples and locations computed in QIIME was composed of seven OTUs, most of them classified as Ascomycota phylum (Table 4). At species level, they showed similarity to Ascomycota Cordyceps confragosa (OTU 822), 
Fig. 1 Bipartite network connecting the fungal OTU nodes to the Amazonian Dark Earth (ADE) and adjacent (ADJ) soil nodes by Açutuba (ACU), Balbina (BAL), Barro Branco (BBO), and Hatahara (HAT) representing edges (a) and canonical correspondence analysis (CCA) with $95 \%$ confidence ellipses (b)

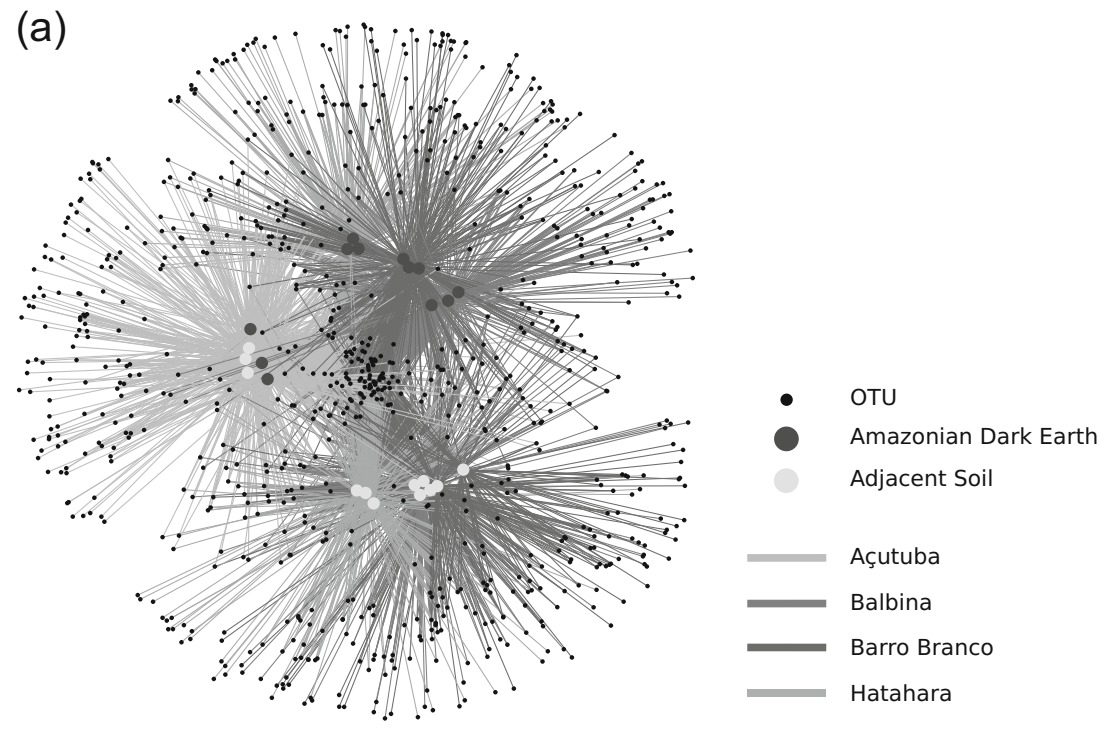

(b)

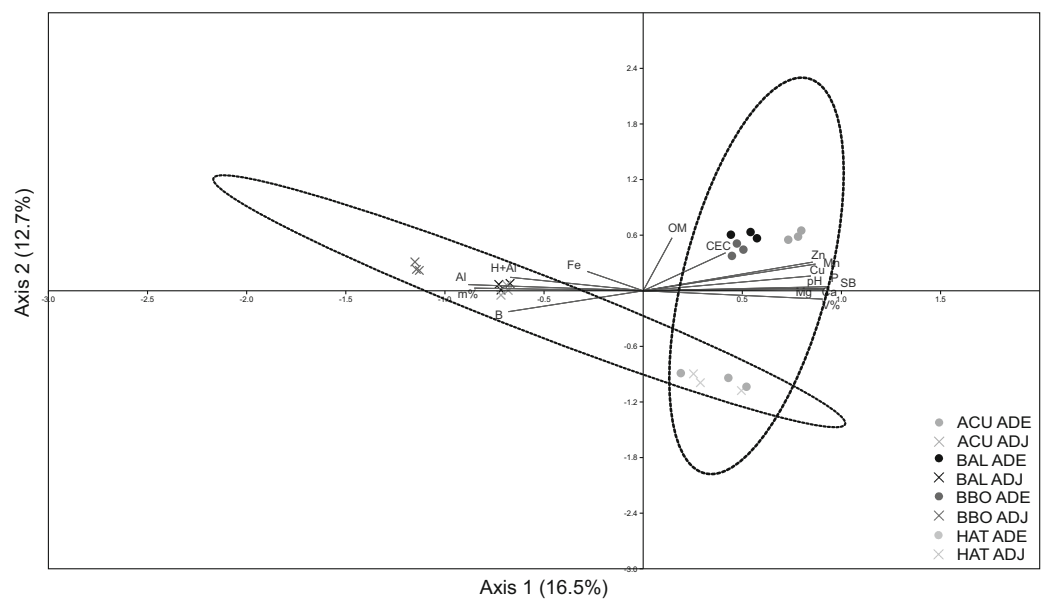

Lithothelium septemseptatum (OTU 1344), Aspergillus niger (OTU 2196), Ophiocordyceps clavata (OTU 2207), and Fomitopsis pinicola (Basidiomycota, OTU 153), and OTUs 874 and 1924 were classified as uncultured fungus (Table 4).

We also determined the fungal cores in the ADE and ADJ that were present in all samples of the same group but not necessary completely absent in the other one. Due to the particular grouping patterns of the ACU soil samples in the OTU network and CCA analyses (Fig. 1a, b), we decided to compute the fungal core in two ways: including and excluding ACU samples. By considering only the most homogeneous ADE and ADJ sites (BAL, BBO, and HAT), we increased the number of OTUs in the core. The ADE core considering all sites was composed of six OTUs; of those, three had similarity to Mortierellaceae sp. (OTUs 991, 1943, and 2141), one to Plectosphaerella sp. (OTU 2425), and the other two had similarity to uncultured Chytridiomycota (OTU 1462) and uncultured Boletaceae (OTU 1134) (Table 4). After ACU ADE sequence exclusion, the ADE core was increased to 15 OTUs and a higher diversity was observed (Table 4). The ADJ core considering all sites was composed of eight OTUs: two similar to Mucoromycotina sp. (OTUs 2315 and 2057) and the others similar to Exophiala dermatitidis (OTU 118), Acremonium vitellinum (OTU 468), Pestalosphaeria sp. (OTU 938), Cryptococcus aureus (OTU 1002), uncultured Basidiomycota (OTU 1523), and Spathularia flavida (OTU 2120). After ACU ADJ sequence removal, the number of OTUs belonging to ADJ fungal core was raised to 12 OTUs (Table 4).

\section{Abundance-Based Analyses}

The dominant OTUs present in at least $75 \%$ of the ADE and ADJ 18S rRNA soil libraries ( $>1 \%$ of sequences of each group) were identified and tested for statistical significant differences in abundance (non-parametric $t$ test followed by Monte Carlo test). Of the 30 OTUs that fit this criterion, 12 were more abundant in ADE soils, 10 in ADJ soils, and 8 showed no significant abundance differences between soil 


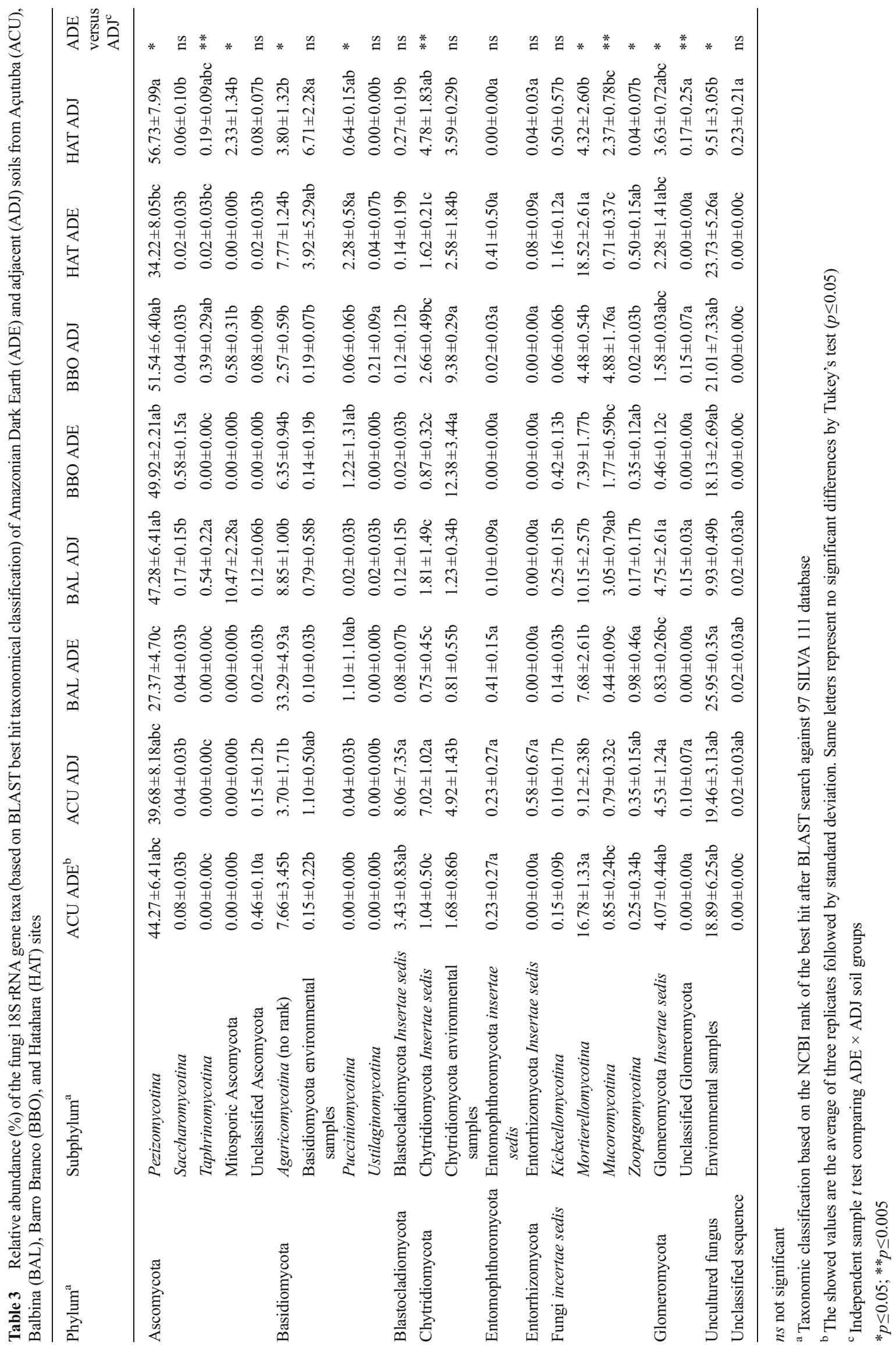


Table 4 Amazonian Dark Earth (ADE) and adjacent (ADJ) soils general fungal OTU core and specific soil type cores (ADE or ADJ) followed by the best BLAST hit and the NCBI taxonomical classification

\begin{tabular}{|c|c|c|c|c|c|}
\hline \multirow[b]{2}{*}{ OTU number } & \multirow[b]{2}{*}{ Soil group } & \multirow[b]{2}{*}{ Access number } & \multicolumn{3}{|c|}{ NCBI taxonomic classification ${ }^{\mathrm{a}}$} \\
\hline & & & Phylum & Subphylum & Specie \\
\hline OTU 153 & $\mathrm{ADE} / \mathrm{ADJ}$ & AY705967 & Basidiomycota & Agaricomycotina (no rank) & Fomitopsis pinicola \\
\hline OTU 822 & $\mathrm{ADE} / \mathrm{ADJ}$ & AB111495 & Ascomycota & Pezizomycotina & Cordyceps confragosa \\
\hline OTU 874 & $\mathrm{ADE} / \mathrm{ADJ}$ & JN054669 & nd & nd & Uncultured fungus \\
\hline OTU 1344 & $\mathrm{ADE} / \mathrm{ADJ}$ & AY584662 & Ascomycota & Pezizomycotina & Lithothelium septemseptatum \\
\hline OTU 2196 & $\mathrm{ADE} / \mathrm{ADJ}$ & GQ903337 & Ascomycota & Pezizomycotina & Aspergillus niger \\
\hline OTU 2207 & $\mathrm{ADE} / \mathrm{ADJ}$ & JN941726 & Ascomycota & Pezizomycotina & Ophiocordyceps clavata \\
\hline OTU 1924 & $\mathrm{ADE} / \mathrm{ADJ}$ & JN054669 & nd & nd & Uncultured fungus \\
\hline OTU 991 & $\mathrm{ADE}$ & EU688964 & Fungi incertae sedis & Mortierellomycotina & Mortierellaceae sp. \\
\hline OTU 1943 & $\mathrm{ADE}$ & EU688964 & Fungi incertae sedis & Mortierellomycotina & Mortierellaceae sp. \\
\hline OTU 2141 & $\mathrm{ADE}$ & EU688964 & Fungi incertae sedis & Mortierellomycotina & Mortierellaceae sp. \\
\hline OTU 2425 & $\mathrm{ADE}$ & HQ871881 & Ascomycota & Pezizomycotina & Plectosphaerella sp. \\
\hline OTU 1462 & $\mathrm{ADE}$ & GQ995336 & Chytridiomycota & nd & uncultured Chytridiomycota \\
\hline OTU 1134 & $\mathrm{ADE}$ & EF024156 & Basidiomycota & Agaricomycotina (no rank) & uncultured Boletaceae \\
\hline OTU $310^{\mathrm{b}}$ & $\mathrm{ADE}$ & GU369995 & nd & nd & Uncultured marine eukaryote \\
\hline OTU $339^{\mathrm{b}}$ & $\mathrm{ADE}$ & DQ198797 & Basidiomycota & Pucciniomycotina & Atractiella solani \\
\hline OTU $362^{\mathrm{b}}$ & $\mathrm{ADE}$ & GU568155 & nd & nd & Uncultured soil fungus \\
\hline OTU $548^{\mathrm{b}}$ & $\mathrm{ADE}$ & JN941713 & Ascomycota & Pezizomycotina & Ophiocordyceps nutans \\
\hline OTU $1526^{\mathrm{b}}$ & $\mathrm{ADE}$ & AF026592 & Basidiomycota & Agaricomycotina (no rank) & Bjerkandera adusta \\
\hline OTU $1878^{\mathrm{b}}$ & $\mathrm{ADE}$ & ABIS01004081 & Ascomycota & Pezizomycotina & Coccidioides posadasii \\
\hline OTU $2075^{\mathrm{b}}$ & $\mathrm{ADE}$ & EU417636 & Glomeromycota & Incertae sedis & Uncultured Glomus \\
\hline OTU $2282^{b}$ & $\mathrm{ADE}$ & AB196322 & Fungi incertae sedis & Kickxellomycotina & Ramicandelaber longisporus \\
\hline OTU $2475^{\mathrm{b}}$ & $\mathrm{ADE}$ & AB901634 & nd & nd & Uncultured eukaryote \\
\hline OTU118 & ADJ & DQ823107 & Ascomycota & Pezizomycotina & Exophiala dermatitidis \\
\hline OTU 468 & ADJ & HQ232212 & Ascomycota & Pezizomycotina & Acremonium vitellinum \\
\hline OTU 938 & ADJ & AF104356 & Ascomycota & Pezizomycotina & Pestalosphaeria sp. \\
\hline OTU 1002 & ADJ & DQ437076 & Basidiomycota & Agaricomycotina (no rank) & Cryptococcus aureus \\
\hline OTU 1523 & ADJ & EF441962 & Basidiomycota & nd & Uncultured Basidiomycota \\
\hline OTU 2120 & ADJ & Z30239 & Ascomycota & Pezizomycotina & Spathularia flavida \\
\hline OTU 2315 & ADJ & JF414214 & Fungi incertae sedis & Mucoromycotina & Mucoromycotina sp. \\
\hline OTU 2057 & ADJ & JF414228 & Fungi incertae sedis & Mucoromycotina & Mucoromycotina sp. \\
\hline OTU $1853^{\mathrm{b}}$ & ADJ & HQ333479 & Ascomycota & Mitosporic (no rank) & Heliocephala gracilis \\
\hline OTU $1086^{\mathrm{b}}$ & ADJ & AB032629 & Basidiomycota & Agaricomycotina (no rank) & Cryptococcus flavus \\
\hline OTU $2235^{\mathrm{b}}$ & ADJ & JF836023 & Ascomycota & Taphrinomycotina & Archaeorhizomyces borealis \\
\hline OTU $2242^{b}$ & ADJ & GQ995264 & Chytridiomycota & nd & Uncultured Chytridiomycota \\
\hline
\end{tabular}

$n d$ not determined (nd)

${ }^{\text {a }}$ Taxonomic classification based on best BLAST hit access after search against SILVA database (97 SILVA 111 taxa map euks) (Quast et al. 2013)

${ }^{\mathrm{b}}$ Present only in Balbina, Barro Branco, and Hatahara sites

origins (Fig. 2). OTU 822, similar to C. confragosa, showed the highest number of $18 \mathrm{~S}$ rRNA sequences $(17.8 \%)$ and was more abundant in the ADE soils (Fig. 2a) than in ADJ soils. The second most abundant was OTU 2196 (6.4\%), similar to A. niger, and significantly more abundant in ADJ soils (Fig. 2b) than ADE soils. Chytridiomycota-like OTUs also showed high abundance levels but without differences based on the soil origin (Fig. 2c).

\section{Discussion}

Up to date, the fungal community in ADE has been characterized only by culture-dependent methods [16] and poorly described when compared to Bacteria and Archaea communities [7-10, 12, 31, 32]. To our knowledge, this is the first study assessing the soil fungal composition and diversity of ADE sites in the Brazilian Central Amazonia compared to 
(a)

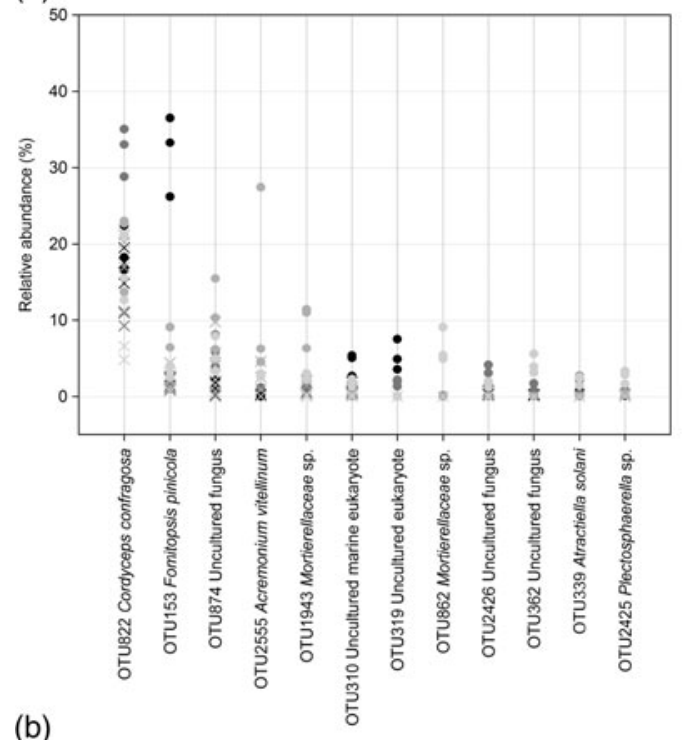

(b)

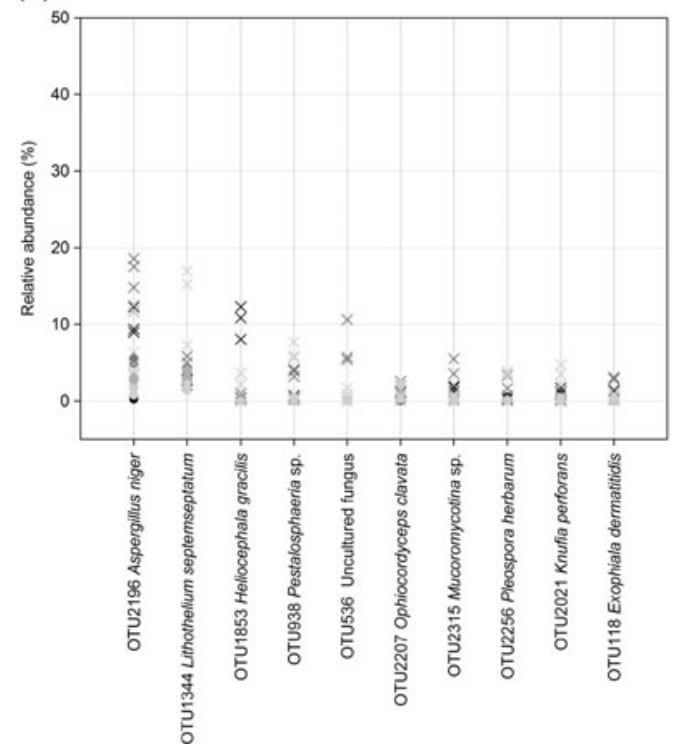

Fig. 2 Differential frequencies of most abundant OTUs $(>1 \%$ of the group sequences) determined by non-parametric $t$ test using Monte Carlo simulation (100 replicates). Plots representing the OTUs statistically

their respective adjacent non-anthropogenic origin soils by using high-throughput $18 \mathrm{~S}$ rRNA gene sequencing. No difference in the fungus species richness was observed between ADE and ADJ soils, with the exception of the HAT site, in which higher species richness in ADE was found with the ACE index. This finding diverges from the bacterial community richness that was described being $25 \%$ greater in ADE soils than in ADJ [7]. Culture-dependent [8] and culture-independent analysis [12] also showed a higher bacterial diversity in ADE in comparison with ADJ soils. However, for fungi, we have detected no differences in fungal diversity in ACU and HAT soils. Only the reciprocal of Simpson's index estimated a lower diversity in BAL and $\mathrm{BBO} \mathrm{ADE}$, indicating possible fungal species dominance. (c)

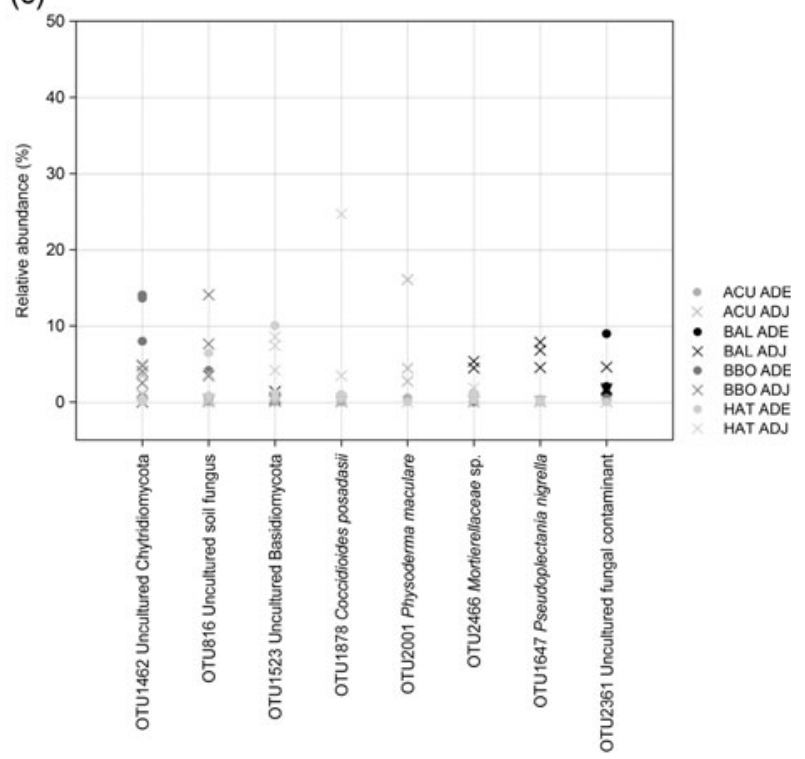

significant most abundant in Amazonian Dark Earth (ADE) (a), in adjacent (ADJ) soils (b), and showing no significant differences between the soil types (c)

Despite the lower fungal species richness and diversity observed in our study, elevated ratios of amino sugar and muramic acid in soil microbial biomass indicated a general predominance of fungi over bacteria in the ADE samples [6].

Previous studies revealed that ADE samples from different origins harbor similar bacterial and archaeal communities as well as bacterial functional genes (e.g., $b p h$, encoding for a biphenyl dioxygenase) that are distinct from adjacent soils of nonanthropogenic origin $[9,33]$. In this study, we observed the same pattern for fungal communities. The ADE fungal communities in three of the four evaluated sites (BAL, BBO, and HAT) were more similar to each other than their respective ADJ soils at OTU level analysis, thus suggesting an effect of past land use 
on the fungal community selection. Nevertheless, the same grouping pattern was not observed for the ACU site where the fungal communities could not be segregated by soil type and were more dissimilar from the other ADE and ADJ sites. Currently, the ACU ADE have intensively been used for agriculture under annual crop rotation system (e.g., eggplant, cowpea, cabbage, zucchini, cucumber, passion fruit, papaya) [34] and also showed the lowest amount of organic matter among the surveyed ADE soils. Shifts in fungal communities in Amazonian soils due to land use changes, e.g., conversion of native forest to pasture and agriculture, have already been described [35], but the extension of the alterations in ADE land use on the microbial communities are still scarce [4]. We observed an increase in the common ADE OTUs (ADE fungal core) after ACU sample removal, but we cannot affirm that this effect was a result of the ACU ADE transformations in response to more intensive land use or due to natural differences in $\mathrm{ADE}$ ages or formation processes. The low concentration of $\mathrm{Al}$ and aluminum saturation in ADJ soil from ACU points to prior lime application before sampling, which could explain the out-grouping of ADJ samples. Lehmann [36] suggests that the specific microbial composition in $\mathrm{ADE}$ is a result of its unique conditions rather than the cause. Indeed, the higher amounts of nutrients, mainly $\mathrm{P}, \mathrm{Ca}, \mathrm{Zn}$, and $\mathrm{Mg}$, and higher $\mathrm{SB}$ and $\mathrm{V} \%$ were associated with $\mathrm{ADE}$ fungal communities, whereas $\mathrm{Al}$ and aluminum saturations were more associated to the fungal communities in ADJ soils. High levels of $\mathrm{Al}$ and $\mathrm{Mn}$ indirectly caused by soil $\mathrm{pH}$ acidity have been described as a limiting factor for crop production in Amazonian soils [37]. Significant correlations of $\mathrm{Al}$ contents in $\mathrm{ADE}$ and $\mathrm{ADJ}$ soils with bacterial rizhospheric and $b p h$ gene community structures were also observed [4, 33]; however, further studies are still necessary to confirm this assumptions for fungal communities in these environments.

The microbial functions in ADE are still unclear [36], and most hypothesis relies on black carbon (BC) oxidation, mainly by fungi [6] or $\mathrm{BC}$ biological production [38]. Due to its polycyclic aromatic structure, $\mathrm{BC}$ cannot be considered an available source of $\mathrm{C}$ for microbial growth [3, 39]; however, it may be mineralized by microbial co-metabolism [9]. In our survey, we observed a significantly higher abundance in ADE of OTUs showing similarity to the brown rot fungi $F$. pinicola [40] as well as the saprophytic fungi $A$. vitellinum [41] and Mortierellaceae sp. LN07-7-4. A remarkable characteristic of the Basidiomycota brown rot fungi is the selective degradation of wood polysaccharides, which avoids lignin molecules [42]. In the same way, Mortierella spp. and Acremonium spp. were found in thermophilic compost and vermicompost [43-45]. Mortierellales fungi were more associated to manure silage and hay compost than hardwood composts [45]. Mortierellacea was also described as dominant in soil samples from primary florets and agricultural areas in Amazonia [35]. Based on these results, we hypothesize that the most abundant fungal species in $\mathrm{ADE}$ are involved in the decomposition of fresh organic matter instead of direct oxidation of recalcitrant $\mathrm{BC}$. However, the potential for lower $\mathrm{BC}$ oxidation rates by the Agaricomycotina fungi cannot be discarded and should be investigated in the future. We were unable to affirm in this study if the decomposition of fresh organic matter priming affected recalcitrant $\mathrm{BC}$ decomposition. Controversial results are observed in the literature showing positive effect of glucose on $\mathrm{BC}$ oxidation in $\mathrm{BC} /$ sandy mixture [46] and no priming effect on $\mathrm{BC}$ mineralization by the incorporation of ${ }^{13} \mathrm{C}$-labeled plant residues to $\mathrm{ADE}$ in long-term experiments [39]. In the other direction, Glaser and Knorr [38] determined significant amounts of biological $\mathrm{BC}$ production under humid tropical conditions and attributed it to the black pigment aspergilin produced by Aspergillus niger. Despite the presence of A. niger in the general fungal core, the OTU 2196 similar to this species was significantly abundant in the ADJ soils. A. niger is a versatile ubiquitous fungus, commonly found in soil and litter [47], and able to produce and secrete enzymes and siderophore molecules [48] and solubilize inorganic P [49].

In this study, we also observed a high abundance of $18 \mathrm{~S}$ rRNA sequences similar to the fungal species $C$. confragosa, a pathogen of arthropods and other fungal species [50]. Entomopathogenic fungi, like Cordyceps and Ophiocordyceps, are commonly found in undisturbed tropical humid forests soil and litter and can control insect outbreaks [51]. C. confragosa, also known as Lecanicillium lecanii (Zimm.) during its anamorphic stage, is a parasite of the green coffee scale (Coccus viridis, Hemiptera) [52] and coffee leaf rust fungus (Hemileia vastatrix) [53]. In agricultural environments, soil can act as the fungus propagule reservoir during the dry seasons and absence of the target insects [54]. We observed a dominance of $C$. confragosa-like OTUs in the BBO ADE soil that was cultivated with a citrus orchard and speculate that this fungus could be acting in the insect biological control. Further studies are necessary to explore these predictions. Our findings indicated that beyond the importance in $\mathrm{C}$ transformations, ADE soils could be a source of new entomopathogenic fungi.

\section{Conclusions}

Our study revealed that fungi communities in ADE were more similar to each other than to the adjacent soils, even when considering the different origins and ages of formation. The concentrations of soil $\mathrm{P}$ and $\mathrm{Al}$ were the main chemical properties associated to the fungal assemblages in ADE and ADJ soils, respectively. However, other potential factors driving ADE fungi communities beyond the soil chemical attributes might be further investigated. Recently, it was demonstrated that plant species can influence rhizospheric bacterial communities in ADE [4]. The most abundant OTUs in the ADE soils showed similarity to saprophytic fungi species related to fresh 
organic matter degradation. Studies of the functional diversity of fungi in ADE and the relation with soil organic matter degradation are necessary $[31,36]$ and should be considered as next step in ADE research.

Acknowledgments We thank Prof. Zaida I. Antoniolli, coordinator of CAPES/NUFFIC (project 057/2014), Mattias de Hollander for bioinformatics support, and Noriko Cassman for manuscript language editing. This work was supported by Joint Research Projects in Biobased Economy (grant number 13/50365-5) from São Paulo Research Foundation (FAPESP) and The Netherlands Organization for Scientific Research (NWO) and FAPESP grant numbers 07/54266-0, 11/50914-3. ARL scholarship was financed by Coordenação de Aperfeiçoamento de Pessoal de Nível Superior (CAPES) and CAPES/NUFFIC grant number 057/2014. FSC scholarship was financed by Conselho Nacional de Desenvolvimento Científico (CNPq) (grant numbers 564163/2008-2 and 485801/2011-6). Publication 5944 of the Netherlands Institute of Ecology (NIOO-KNAW).

Open Access This article is distributed under the terms of the Creative Commons Attribution 4.0 International License (http:// creativecommons.org/licenses/by/4.0/), which permits unrestricted use, distribution, and reproduction in any medium, provided you give appropriate credit to the original author(s) and the source, provide a link to the Creative Commons license, and indicate if changes were made.

\section{References}

1. Sombroek WG (1966) Amazon soils: a reconnaissence of the soils of the Brazilian Amazon region. Pudoc, Wageningen

2. Glaser B (2007) Prehistorically modified soils of central Amazonia: a model for sustainable agriculture in the twenty-first century. Philos Trans R Soc Lond B Biol Sci 362:187-196. doi:10.1098/ rstb.2006.1978

3. Glaser B, Haumaier L, Guggenberger G, Zech W (2001) The "Terra Preta" phenomenon: a model for sustainable agriculture in the humid tropics. Naturwissenschaften 88:37-41. doi:10.1007/ s001140000193

4. Lima AB, Cannavan FS, Navarrete AA et al (2015) Amazonian Dark Earth and plant species from the Amazon region contribute to shape rhizosphere bacterial communities. Microb Ecol 69:855866. doi:10.1007/s00248-014-0472-8

5. Neves EG, Petersen JB, Bartone RN, da Silva CA (2003) Historical and socio-cultural origins of Amazonian Dark Earths. In: Lehmann $\mathrm{J}$ et al (eds) Amazonian Dark Earths: origin, properties, management. Kluwer Academic Publisher, Dordrecht, pp 29-50

6. Glaser B, Birk JJ (2012) State of the scientific knowledge on properties and genesis of anthropogenic Dark Earths in central Amazonia (Terra Preta de Índio). Geochim Cosmochim Acta 82: 39-51. doi:10.1016/j.gca.2010.11.029

7. Kim J-S, Sparovek G, Longo RM et al (2007) Bacterial diversity of Terra Preta and pristine forest soil from the Western Amazon. Soil Biol Biochem 39:684-690. doi:10.1016/j.soilbio.2006.08.010

8. O'Neill B, Grossman J, Tsai SM et al (2009) Bacterial community composition in Brazilian Anthrosols and adjacent soils characterized using culturing and molecular identification. Microb Ecol 58: 23-35. doi:10.1007/s00248-009-9515-y

9. Grossman JM, O'Neill BE, Tsai SM et al (2010) Amazonian Anthrosols support similar microbial communities that differ distinctly from those extant in adjacent, unmodified soils of the same mineralogy. Microb Ecol 60:192-205. doi:10.1007/s00248-0109689-3

10. Navarrete AA, Cannavan FS, Taketani RG, Tsai SM (2010) A molecular survey of the diversity of microbial communities in different amazonian agricultural model systems. Diversity 2:787-809. doi: $10.3390 / \mathrm{d} 2050787$

11. Roesch LFW, Fulthorpe RR, Riva A et al (2007) Pyrosequencing enumerates and contrasts soil microbial diversity. ISME J 1:283290. doi:10.1038/ismej.2007.53

12. Taketani RG, Lima AB, da Conceição Jesus E et al (2013) Bacterial community composition of anthropogenic biochar and Amazonian Anthrosols assessed by $16 \mathrm{~S}$ rRNA gene 454 pyrosequencing. Antonie Van Leeuwenhoek 104:233-242. doi:10.1007/s10482013-9942-0

13. Kuramae EE, Hillekens RHE, de Hollander M et al (2013) Structural and functional variation in soil fungal communities associated with litter bags containing maize leaf. FEMS Microbiol Ecol 84:519-531. doi:10.1111/1574-6941.12080

14. Kuramae EE, Verbruggen E, Hillekens R et al (2013) Tracking fungal community responses to maize plants by DNA- and RNAbased pyrosequencing. PLoS One 8:e69973. doi:10.1371/journal. pone. 0069973

15. Van der Wal A, Geydan TD, Kuyper TW, de Boer W (2013) A thready affair: linking fungal diversity and community dynamics to terrestrial decomposition processes. FEMS Microbiol Rev 37: 477-494. doi:10.1111/1574-6976.12001

16. Ruivo M de LP, Amarante CB do, Oliveira M de LS, Muniz ICM, Santos DAM dos (2009) Microbial population and biodiversity in Amazonian Dark Earth soils. In: Woods WI et al. (eds) Amazonian Dark Earths: Wim Sombroek's vision. Springer Science, Dordrecht, pp 351-362

17. Nakamura F, Germano M, Tsai SM (2014) Capacity of aromatic compound degradation by bacteria from Amazon Dark Earth. Diversity 6:339-353. doi:10.3390/d6020339

18. Rebellato L, Woods WI, Neves EG (2009) Pre-Columbian settlement dynamics in the Central Amazon. In: Woods WI et al. (eds) Amazonian Dark Earths: Wim Sombroek's vision. Springer Science, Dordrecht, pp 15-32

19. van Raij B, Andrade JC, Cantarella H, Quaggio JA (2001) Análise química para avaliação de fertilidade de solos tropicais. Instituto Agronômico de Campinas, Campinas

20. Vainio EJ, Hantula J (2000) Direct analysis of wood-inhabiting fungi using denaturing gradient gel electrophoresis of amplified ribosomal DNA. Mycol Res 104:927-936. doi:10.1017/ S0953756200002471

21. Verbruggen E, Kuramae EE, Hillekens R et al (2012) Testing potential effects of maize expressing the Bacillus thuringiensis Cry1 $\mathrm{AB}$ endotoxin (Bt maize) on mycorrhizal fungal communities via DNA- and RNA-based pyrosequencing and molecular fingerprinting. Appl Environ Microbiol 78:7384-7392. doi:10.1128/ AEM.01372-12

22. Caporaso JG, Kuczynski J, Stombaugh J et al (2010) QIIME allows analysis of high-throughput community sequencing data. Nat Methods 7:335-336. doi:10.1038/nmeth.f.303

23. Reeder J, Knight R (2010) Rapidly denoising of pyrosequencing amplicon data: exploiting the rank-abundance distribution. Nat Methods 7:668-669. doi:10.1038/nmeth0910-668b

24. Edgar RC, Haas BJ, Clemente JC et al (2011) UCHIME improves sensitivity and speed of chimera detection. Bioinformatics 27: 2194-2200. doi:10.1093/bioinformatics/btr381

25. Edgar RC (2010) Search and clustering orders of magnitude faster than BLAST. Bioinformatics 26:2460-2461. doi:10.1093/ bioinformatics/btq461

26. Altschul SF, Gish W, Miller W, Myers EW, Lipman DJ (1990) Basic local alignment search tool. J Mol Biol 215:403-410 
27. Quast C, Pruesse E, Yilmaz P et al (2013) The SILVA ribosomal RNA gene database project: improved data processing and webbased tools. Nucleic Acids Res 41:D590-D596. doi:10.1093/nar/ gks 1219

28. Chao A, Wang YT, Jost L (2013) Entropy and the species accumulation curve: a novel entropy estimator via discovery rates of new species. Methods Ecol Evol 4:1091-1100. doi:10.1111/2041-210X. 12108

29. Saito R, Smoot ME, Ono K et al (2012) A travel guide to cytoscape plugins. Nat Methods 9:1069-1076. doi:10.1038/nmeth.2212

30. Hammer $\varnothing$, Harper DAT, Ryan PD (2001) Paleontological statistics software package for education and data analysis. Palaeontol Electron 4:9-18. doi:10.1016/j.bcp.2008.05.025

31. Tsai SM, O’Neill B, Cannavan FS et al (2009) The microbial world of Terra Preta. In: Woods WI et al (eds) Amazonian Dark Earths: Wim Sombroek's vision. Springer Science, Dordrecht, pp 299-308

32. Taketani RG, Tsai SM (2010) The influence of different land uses on the structure of archaeal communities in Amazonian Anthrosols based on 16S rRNA and amoA genes. Microb Ecol 59:734-743. doi:10.1007/s00248-010-9638-1

33. Brossi MJDL, Mendes LW, Germano MG et al (2014) Assessment of bacterial bph gene in Amazonian Dark Earth and their adjacent soils. PLoS One 9:e99597. doi:10.1371/journal.pone.0099597

34. Falcão NPDS, Borges LF (2006) Efeito da fertilidade de Terra Preta de Índio da Amazônia Central no estado nutricional e na produtividade do mamão hawaí (Carica papaya L.). Acta Amaz 36:401-406. doi:10.1590/S0044-59672006000400001

35. Fracetto GGM, Azevedo LCB, Fracetto FJC et al (2013) Impact of Amazon land use on the community of soil fungi. Sci Agric 70:59 67. doi:10.1590/S0103-90162013000200001

36. Lehmann J (2009) Terra Preta Nova - where to from here? In: Woods WI et al. (eds) Amazonian Dark Earths: Wim Sombroek's vision. Springer Science, Dordrecht, pp 473-486

37. Falcão NPS, Clemente CR, Tsai SM et al (2009) Pedology, fertility, and biology of Central Amazonian Dark Earths. In: Woods WI et al. (eds) Amazonian Dark Earths: Wim Sombroek's vision. Springer Science, Dordrecht, pp 213-238

38. Glaser B, Knorr KH (2008) Isotopic evidence for condensed aromatics from non-pyrogenic sources in soils-implications for current methods for quantifying soil black carbon. Rapid Commun Mass Spectrom 22:935-942

39. Liang B, Lehmann J, Sohi SP et al (2010) Black carbon affects the cycling of non-black carbon in soil. Org Geochem 41:206-213. doi: 10.1016/j.orggeochem.2009.09.007

40. Karsten PA (1881) Symbolae ad mycologiam fennicam. Medd af Ocietas pro Fauna Flora Fenn 6:7-13

41. Summerbell RC, Gueidan C, Schroers HJ et al (2011) Acremonium phylogenetic overview and revision of Gliomastix, Sarocladium, and Trichothecium. Stud Mycol 68:139-162. doi:10.3114/sim. 2011.68.06

42. Rabinovich ML, Bolobova AV, Vasil'chenko LG (2004) Fungal decomposition of natural aromatic structures and xenobiotics: a review. Appl Biochem Microbiol 40:1-17. doi:10.1023/B:ABIM. 0000010343.73266 .08

43. Anastasi A, Varese GC, Marchisio VF (2005) Isolation and identification of fungal communities in compost and vermicompost. Mycologia 97:33-44. doi:10.3852/mycologia.97.1.33

44. De Gannes V, Eudoxie G, Hickey WJ (2013) Insights into fungal communities in composts revealed by 454-pyrosequencing: implications for human health and safety. Front Microbiol 4:1-9. doi:10. 3389/fmicb.2013.00164

45. Neher DA, Weicht TR, Bates ST et al (2013) Changes in bacterial and fungal communities across compost recipes, preparation methods, and composting times. PLoS One 8:e79512. doi:10. 1371/journal.pone.0079512

46. Hamer U, Marschner B, Brodowski S, Amelung W (2004) Interactive priming of black carbon and glucose mineralisation. Org Geochem 35:823-830. doi:10.1016/j.orggeochem.2004.03. 003

47. Klich MA (2002) Biogeography of Aspergillus species in soil and litter. Mycologia 94:21-27

48. Pel HJ, de Winde JH, Archer DB et al (2007) Genome sequencing and analysis of the versatile cell factory Aspergillus niger CBS 513.88. Nat Biotechnol 25:221-231. doi:10.1038/nbt1282

49. Chuang CC, Kuo YL, Chao CC, Chao WL (2007) Solubilization of inorganic phosphates and plant growth promotion by Aspergillus niger. Biol Fertil Soils 43:575-584. doi:10.1007/s00374-006-01403

50. Sung GH, Hywel-Jones NL, Sung JM et al (2007) Phylogenetic classification of Cordyceps and the clavicipitaceous fungi. Stud Mycol 57:5-59. doi:10.3114/sim.2007.57.01

51. Augustyniuk-Kram A, Kram KJ (2012) Entomopathogenic fungi as an important natural regulator of insect outbreaks in forests. In: Blanco AJ (ed) Forest ecossistems - more than just trees. In Tech, Rijeka, pp 265-294

52. Viégas AP (1939) Um amigo do fazendeiro Verticillium lecanii (Zimm.).n comb. O causador do halo branco do Coccus viridis Green. Rev do Inst do Café do Estado São Paulo 14:754-772

53. Jackson D, Skillman J, Vandermeer J (2012) Indirect biological control of the coffee leaf rust, Hemileia vastatrix, by the entomogenous fungus Lecanicillium lecanii in a complex coffee agroecosystem. Biol Control 61:89-97. doi:10.1016/j.biocontrol. 2012.01.004

54. Jackson D, Zemenick K, Huerta G (2012) Occurrence in the soil and dispersal of Lecanicillium lecanii, a fungal pathogen of the green coffee scale (Coccus viridis) and coffee rust (Hemileia vastatrix). Trop Subtrop Agroecosyst 15:389-401 